\title{
Upgrading Feldspar by WHIMS and Flotation Techniques
}

\author{
Somsak Saisinchai ${ }^{\mathrm{a}, *}$, Thitisak Boonpramote ${ }^{\mathrm{b}}$, and Pinyo Meechumna ${ }^{\mathrm{c}}$ \\ Department of Mining and Petroleum Engineering, Faculty of Engineering, Chulalongkorn University, \\ Bangkok 10330, Thailand \\ E-mail: afmnsss@eng.chula.ac.th (Corresponding author),bfmntbp@eng.chula.ac.th, \\ cfmnpmc@eng.chula.ac.th
}

\begin{abstract}
Large reserves of feldspar ores exist in the pegmatite veins at Ban Tak district, Tak province. The main impurities of these deposits are muscovite, biotite and garnet which resulted in high Fe-content that does not meet the raw materials specification for ceramic industry. Chemical compositions of the feldspar ores are $75.93 \% \mathrm{OSiO}_{2}$, $14.34 \% \mathrm{Al}_{2} \mathrm{O}_{3}, 0.63 \% \mathrm{Fe}_{2} \mathrm{O}_{3}, 4.01 \% \mathrm{~K}_{2} \mathrm{O}$ and $4.34 \% \mathrm{Na}_{2} \mathrm{O}$ with the fire test results of $\mathrm{L}=$ 63.10, $\mathrm{a}=2.04$ and $\mathrm{b}=10.56$. The typical specifications of the commercialised feldspar require $\% \mathrm{SiO}_{2},<70 \%, \mathrm{Al}_{2} \mathrm{O}_{3}>17 \%, \mathrm{Fe}_{2} \mathrm{O}_{3}<0.1 \%$ with $\mathrm{K}_{2} \mathrm{O}$ and $\mathrm{Na}_{2} \mathrm{O}$ both $>5 \%$. The traditional method used to remove Fe-bearing minerals is the reverse flotation. However, this method consumes high sulphuric acid which may create the environmental impact for the nearby area if the treatment is not completely done or the accident occurs. The proposed processes combine the typical process of crushing, grinding and classifying, attrition scrubber, with the wet high intensity magnetic separator (WHIMS) and the direct flotation of feldspar. WHIMS is used to remove muscovite, biotite and garnet which are the causes of high Fe-content. The results showed that efficient separation of Fe-bearing minerals could be achieved by WHIMS in the commercial scale and create the environmental friendly manner. The recovery of processed feldspar is $40 \%$ and the chemical compositions of feldspar products are $68.29 \% \mathrm{SiO}_{2}, 18.69 \% \mathrm{Al}_{2} \mathrm{O}_{3}, 0.07 \% \mathrm{Fe}_{2} \mathrm{O}_{3}$, $5.83 \% \mathrm{~K}_{2} \mathrm{O}$ and $6.33 \% \mathrm{Na}_{2} \mathrm{O}$ with the fire test results of $\mathrm{L}=82.10, \mathrm{a}=-0.56$ and $\mathrm{b}=3.23$ which meet the commercial grade of feldspar.
\end{abstract}

Keywords: Feldspar, crushing, grinding, classifying, attrition scrubber, wet high intensity magnetic separator, direct flotation, dry magnetic separator.

ENGINEERING JOURNAL Volume 19 Issue 4

Received 13 October 2014

Accepted 25 December 2014

Published 31 July 2015

Online at http://www.engj.org/

DOI:10.4186/ej.2015.19.4.83 


\section{Introduction}

Feldspar is a term used to describe a group of aluminosilicate minerals containing sodium, potassium and calcium. Sodium-rich feldspar is called albite, having an empirical formula of $\mathrm{NaAlSi}_{3} \mathrm{O}_{8}$, whereas the terms orthoclase and artorthite are used to describe potassium and calcium rich feldspar respectively. A variety of names are given to feldspar minerals, depending on their composition.

Feldspar is a source of alkalies and alumina in the glass and ceramics industries that make the products more transparency. It also reduces the melting temperature and resulted in less energy consumption for the glass and ceramics production. However, the specifications of feldspar to be used as a raw material for these industries are $\% \mathrm{SiO}_{2},<70 \%, \mathrm{Al}_{2} \mathrm{O}_{3}>17 \%, \mathrm{Fe}_{2} \mathrm{O}_{3}<0.1 \%$ with $\mathrm{K}_{2} \mathrm{O}$ and $\mathrm{Na}_{2} \mathrm{O}$ both $>5 \%[1]$. Several studies was conducted to improve the feldspar products to use in the ceramic industries in many countries [2-7].

Thai feldspar reserves are founded in many provinces such as Tak, Uthaithani, Ratchaburi, Nakhonsithammarat, Chiangmai, Lamphun, Sukhothai, and Kanchanaburi. Although most of the reserves are saleable, either directly or after simple processing, it appears that the quality of the feldspar could be increased by applying conventional concentration techniques, i.e. flotation and magnetic separation. Atthanee International Company is one of the commercial feldspar producers in Tak area that produce feldspar from the pegmatite veins. Naturally, feldspars deposit in this area are both sodium and potassium feldspars with the associated minerals such as muscovite, biotite, and garnet as shown in Fig. 1. The chemical compositions of the ore sample are $75.93 \% \mathrm{SiO}_{2}, 14.34 \% \mathrm{Al}_{2} \mathrm{O}_{3}, 0.63 \% \mathrm{Fe}_{2} \mathrm{O}_{3}, 4.01 \% \mathrm{~K}_{2} \mathrm{O}$ $4.34 \% \mathrm{Na}_{2} \mathrm{O}$ and $0.20 \%$ LOI. These ores need to be upgraded in order to meet the commercial specifications.

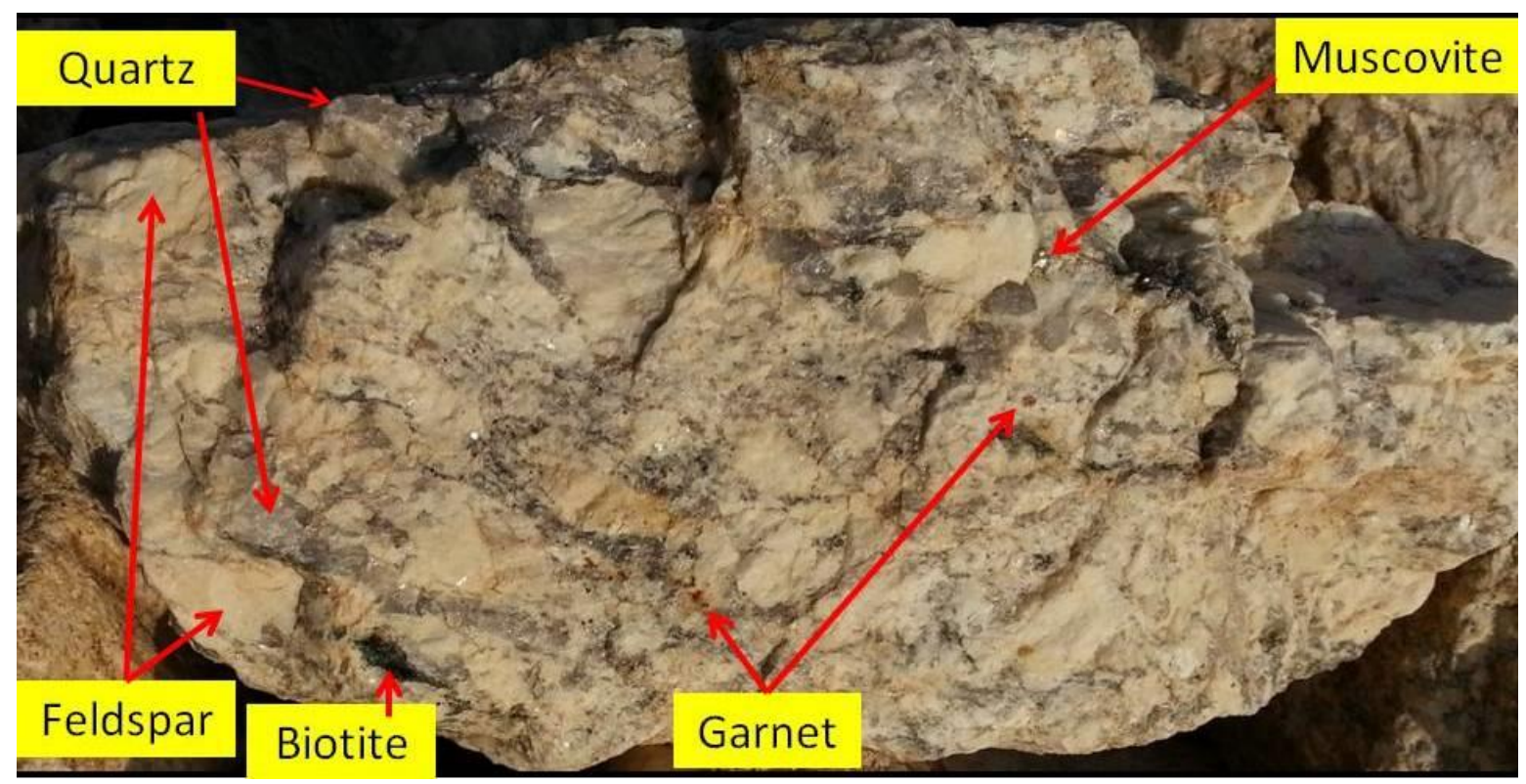

Fig. 1. Ore mineralogy of the feldspar sample.

\section{Concentration Process}

The proposed process used in the commercial scale consists of crushing, grinding classifying, attrition scrubbing, wet high intensity magnetic separation, direct flotation of feldspar and upgrading of feldspar using dry magnetic separators.

\subsection{Crushing}

Feldspar ore is quarried from open pit deposit and transported to the hopper by truck, the grizzly reciprocating feeder feeds the ore that is larger than 1 inch to the jaw crusher with the rate of 25-30 tonnes per hour. Ore particles that are finer than 1 inch will pass through the slots and bypass the jaw crusher and will be washed off the dirt using spiral classifier. Such particles will be mixed with other particles using 
conveyor and feed to the vibrating screen. The 30\% of the particles that are larger than 1 inch will be crushed by the jaw crusher and returned to the vibrating screen once again. Ore particles which are smaller than 1 inch that passed through the conveyor will be put in the coarse ore bin as shown in Fig. 2 and the size distribution of ball mill feed ore as shown in Table 1.

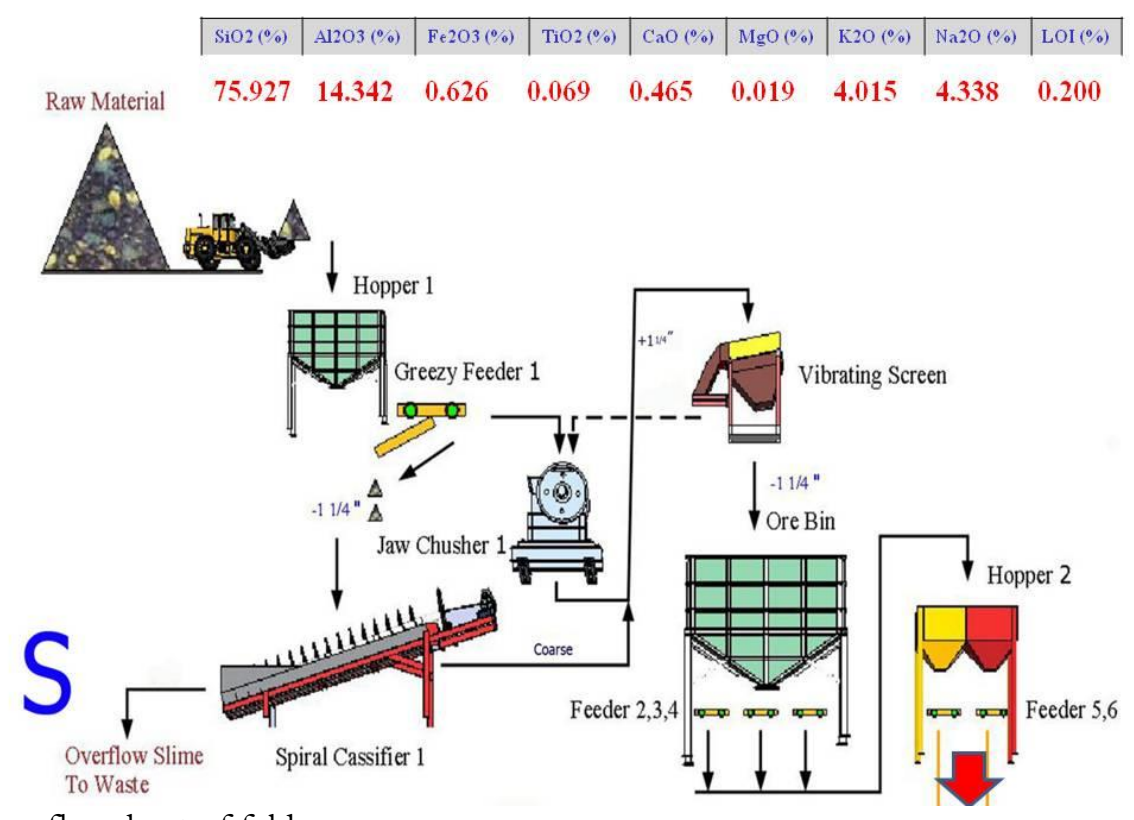

Fig. 2. Crushing flowsheet of feldspar.

Table 1. Size distribution of Ball mill feed ore.

\begin{tabular}{ccc}
\hline Size $\mathbf{( m m})$ & $\mathbf{\%} \mathbf{W t}$ & Cumulative $\mathbf{~} \mathbf{~ W t}$ \\
\hline+25.4 & 0 & 0 \\
$-25.4+9.5$ & 22.5 & 22.5 \\
$-9.5+1.0$ & 57.4 & 79.9 \\
-1.0 & 2.1 & 100 \\
\hline
\end{tabular}

\subsection{Grinding}

For the first line, conveyor will bring the ore from coarse ore bin to the ball mill at the rate of 6 tonnes per hour. Ore that has been grinded will flow into spiral classifier. Ore that is smaller than 30 mesh will be put in the trommel and cone classifier to discard slime 1.2 tonnes per hour that is smaller than 230 mesh. Then feed the coarse fraction to sump by the screw conveyor. Ore that is bigger than 30 mesh will be separated by spiral classifier and grinded with ball mill once again (See Fig. 3).

For the second line, conveyor will take the ore from coarse ore bin to the ball mill at the rate of 2 tonnes per hour. Grinded ore will flow in to the spiral classifier gives the ore that is finer than 30 mesh to the trammel and cone classifier in order to discard slime 0.4 tonnes per hour that is smaller than 230 mesh. Then feed the coarse fraction to sump by the screw conveyor. And the ore that is larger than 30 mesh will be separated by spiral classifier and grinded with the ball mill again. The size distribution of ball mill discharge, spiral classifier under flow and spiral classifier over flow are shown in Table 2, 3 and 4 respectively. 


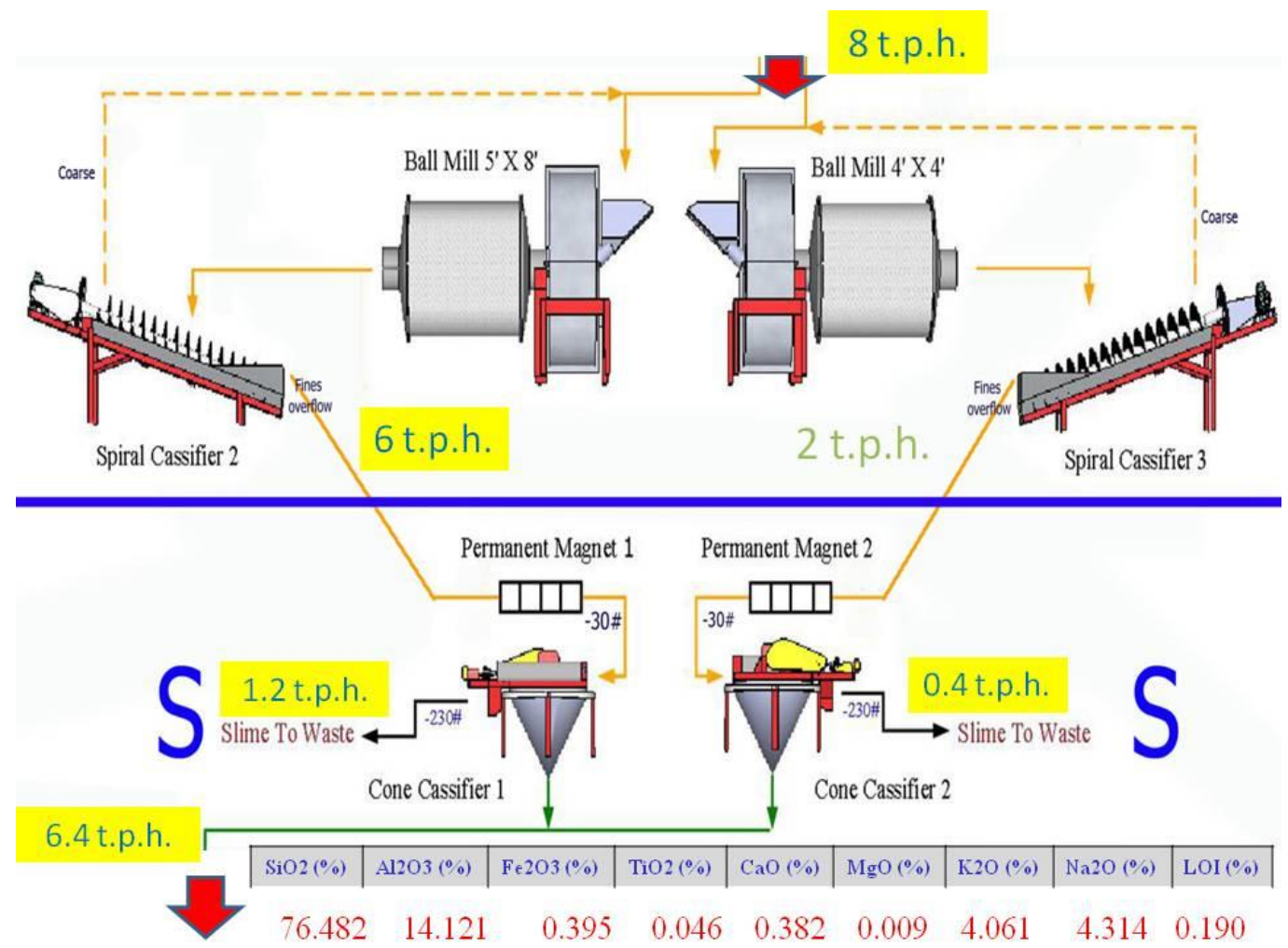

Fig. 3. Feldspar grinding flowsheet.

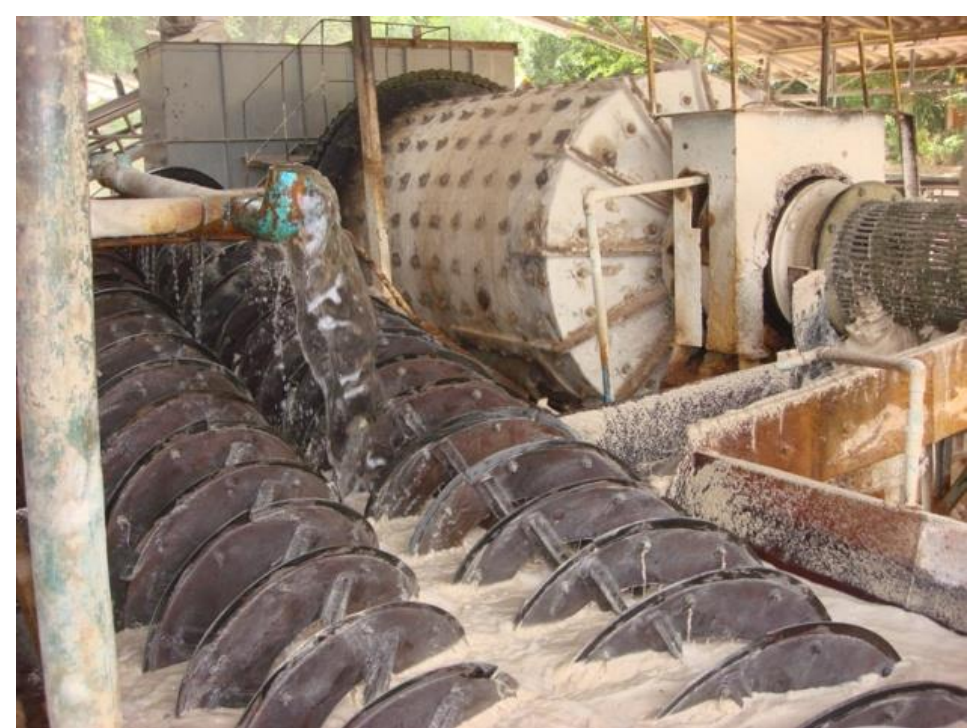

Fig. 4. Arrangement of the feldspar grinding circuit.

Table 2. Size distribution of ball mill discharge.

\begin{tabular}{ccc}
\hline Size $(\mathrm{mesh})$ & $\% \mathrm{Wt}$ & Cumulative $\% \mathrm{Wt}$ \\
\hline 50 & 64.17 & 64.17 \\
$-50+100$ & 26.71 & 90.88 \\
$-100+140$ & 5.03 & 95.91 \\
$-140+230$ & 3.05 & 98.96 \\
-230 & 1.04 & 100 \\
\hline
\end{tabular}


Table 3. Size distribution of spiral classifier underflow.

\begin{tabular}{ccc}
\hline Size $(\mathrm{mesh})$ & $\% \mathrm{Wt}$ & Cumulative $\% \mathrm{Wt}$ \\
\hline 50 & 54.61 & 54.61 \\
$-50+100$ & 32.26 & 86.87 \\
$-100+140$ & 8.12 & 94.99 \\
$-140+230$ & 4.11 & 99.10 \\
-230 & 0.9 & 100 \\
\hline
\end{tabular}

Table 4. Size distribution of Spiral Classifier overflow.

\begin{tabular}{ccc}
\hline Size $(\mathrm{mesh})$ & $\% \mathrm{Wt}$ & Cumulative $\% \mathrm{Wt}$ \\
\hline 50 & 1.88 & 1.88 \\
$-50+100$ & 33.49 & 35.37 \\
$-100+140$ & 33.30 & 68.67 \\
$-140+230$ & 24.35 & 93.02 \\
-230 & 6.98 & 100 \\
\hline
\end{tabular}

\subsection{Wet High Intensity Magnetic Separator}

The slurry will be pumped into 50 mesh trommel to return oversize back to ball mill and undersize passes to cone classifier. High iron content fine ore is rejected by overflow and underflow slurry passes to attrition scrubber tank. This scrubber tank is not only a highly efficient unit for removing surface films, coatings and slimes from sand grains in pulps, but also conditioning the pulps in operations that required the maximum pulp densities of $70 \%$ to $80 \%$ wt. solids. Scrubbing and polishing is accomplished by grain-to-grain attrition chiefly in the zone between the two large diameter opposed propellers. Then the slurry passes to the permanent drum magnetic separator under the magnetic induction of 4,500 gauss to discard any iron scraps. The slurry then flows into the 2 units of the wet high intensity magnetic separator (WHIMS) under the magnetic induction of 14,000 gauss. The separator divides the slurry into 2 fractions, magnetic fraction is mainly mica and garnet and will pass to shaking table, and the non-magnetic fraction is mainly feldspar and quartz and pass to hydrocyclone as shown in Figs. 5 and 6.

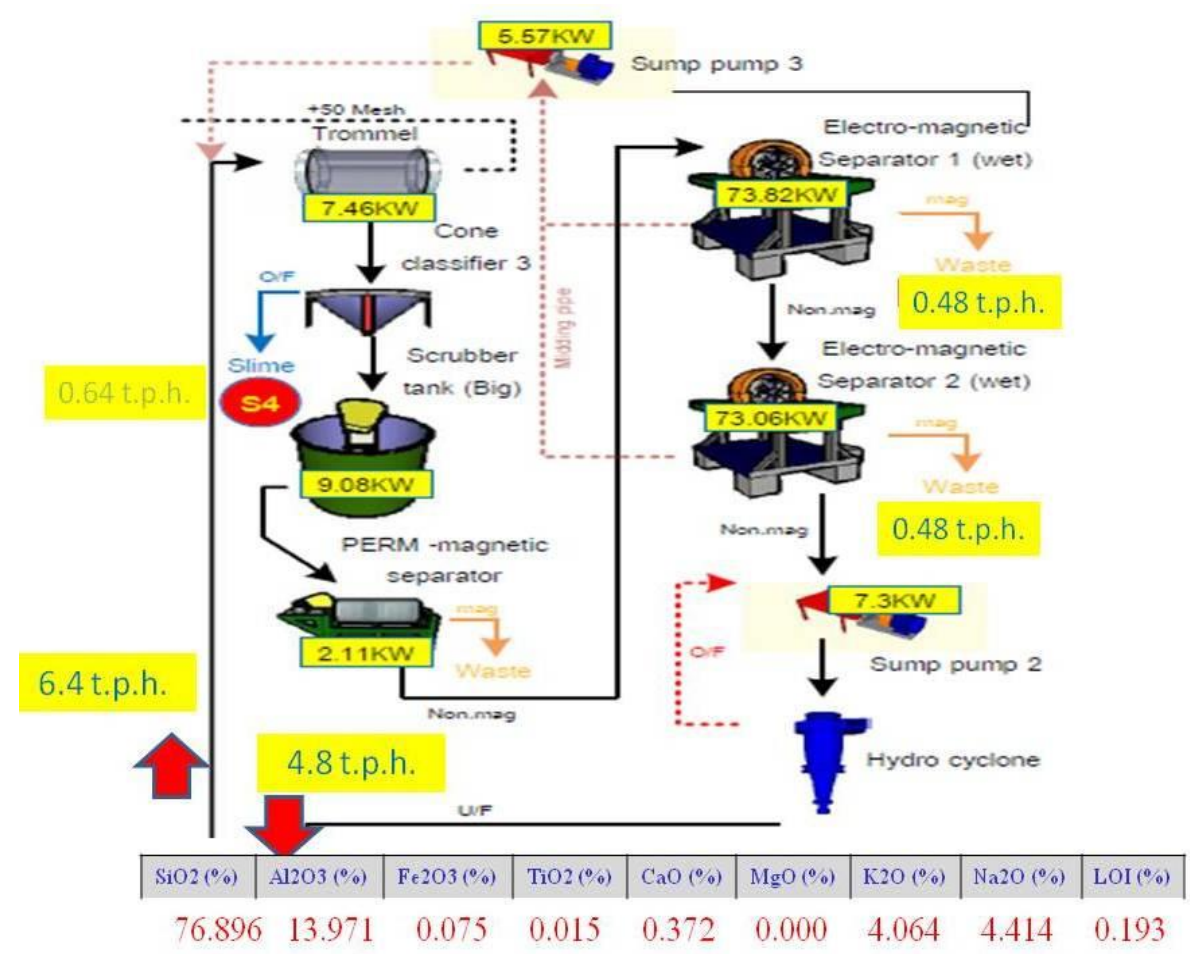

Fig. 5. WHIMS flowsheet of feldspar. 


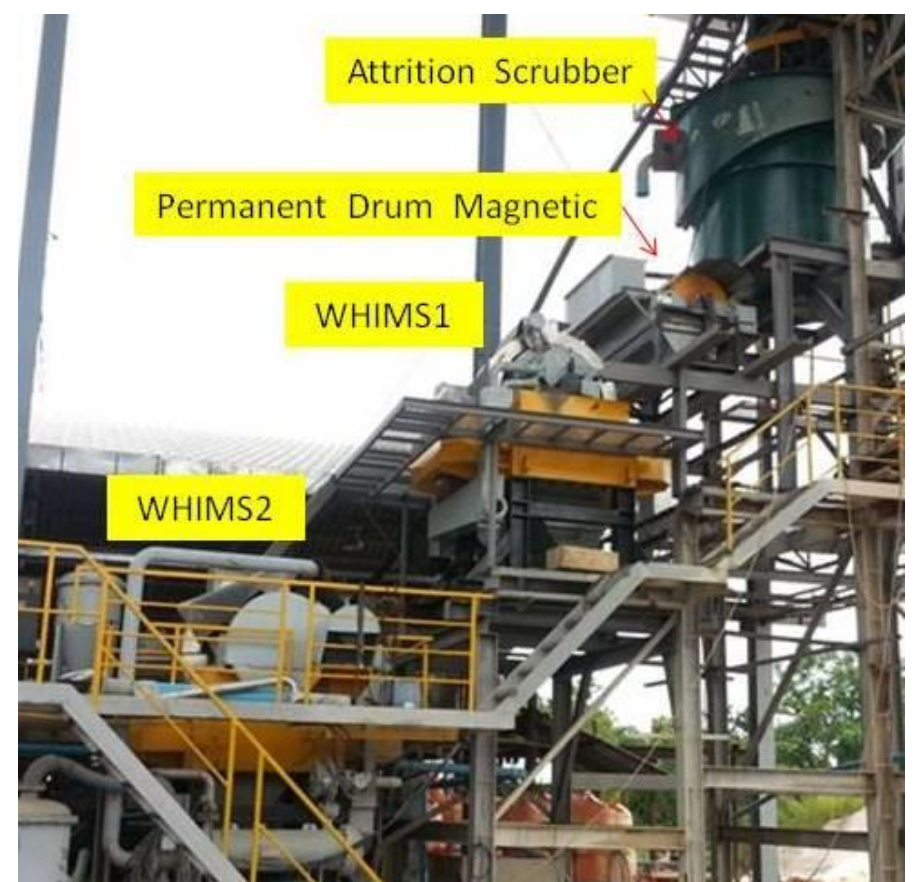

Fig. 6. Appearance of the feldspar wet magnetic circuit.

\subsection{Feldspar Direct Flotation}

The underflow slurry flows into the spiral classifier for dewatering. The sediment ore then modify the surface in the conditioner tank around 15 minutes using hydrofluoric acid at a desired $\mathrm{pH} 3$ together with the collector (amine) about $110 \mathrm{~g} /$ ton feed. Before passing the rougher cell, the frother (pine oil) about 30 $\mathrm{g} /$ ton feed was added into the slurry with the pulp density around $25 \% \mathrm{wt}$. solids in order to float the feldspar out from the quartz. The unfloated ore from rougher cell will pass through 3 scavenger cells to recover the remaining feldspar and feed it in rougher cell. The remaining quartz will be collected in the pond and then pump to another stockpile area.

The floated feldspar from rougher cell flows to the 3 units of attrition tank and the spiral classifier for cleaning the ore's surface. The slurry then pumped to feldspar stockpile area as shown in Figs. 7 and 8.

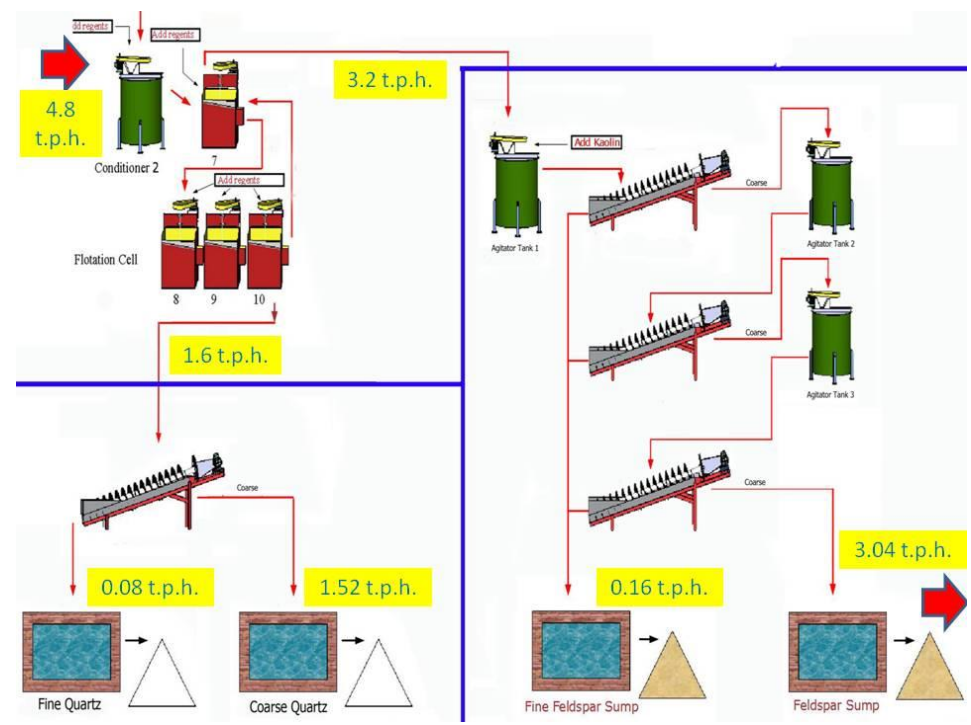

Fig.7. Feldspar flotation flowsheet. 


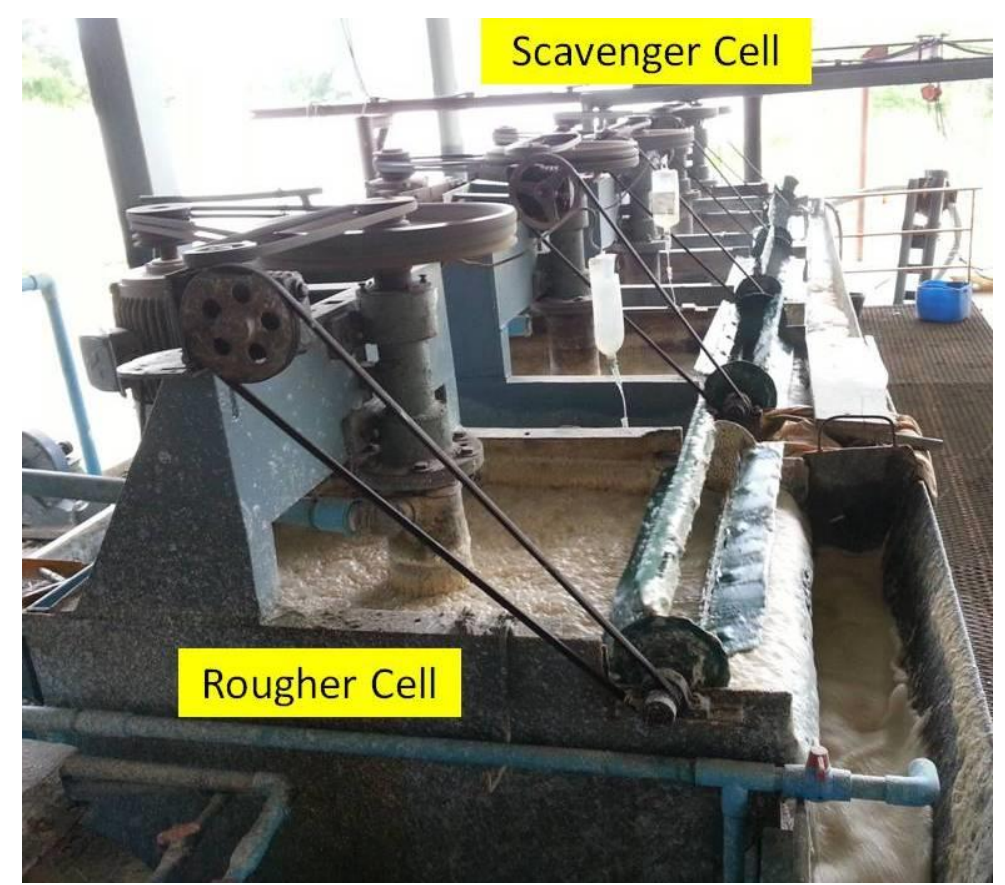

Fig. 8. The feldspar flotation circuit.

\subsection{Upgrading of Feldspar by Dry Magnetic Separator}

From the piles of feldspar, the wheel loader will be used to convey the less moisture ore to the conveyor and put into the rotary dryer to dry it before being transferred to the users.

In case the users want the ore to be perfectly pure, the dried ore must be put into the dry drum permanent magnetic separator to discard iron scraps and passes to the dry high intensity magnetic separator to filter out the impurities iron ore. Then put in the conveyor and the bags, then use the folk lift car for organizing and sending to the users as shown in Fig. 9.

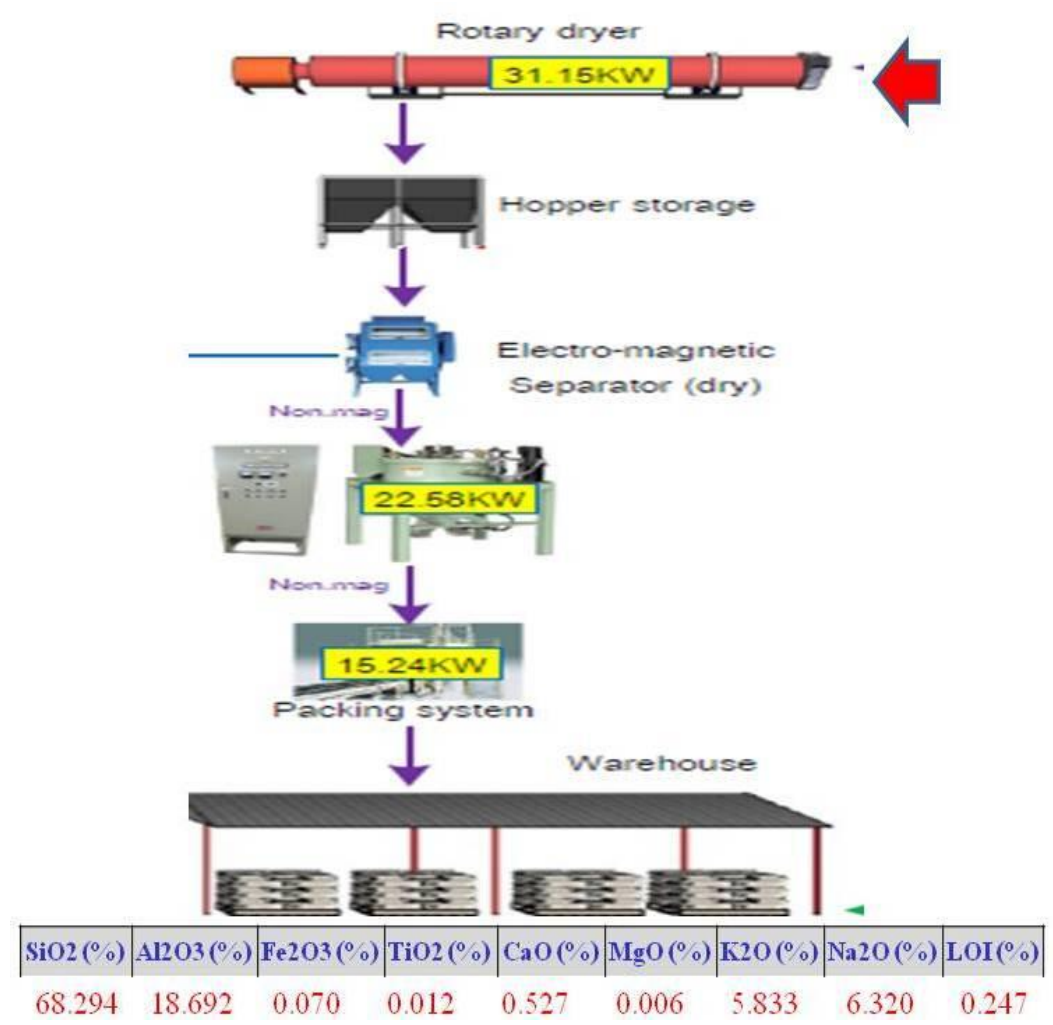

Fig. 9. Dry magnetic flowsheet of feldspar. 


\section{Product Comparisons of The Feldspar Ore and the Processed Products}

The chemical composition of both raw and processed feldspar samples was analyzed using the S2 RANGER BRUKER X-ray fluorescence and the Spectra EDX. Primary X-ray was generated using Palladium Target. High Voltage of $20 \mathrm{kV}$ and 1000-2000 $\mu \mathrm{A}$ was set to measure $\mathrm{Na}, \mathrm{Mg}, \mathrm{Al}, \mathrm{Si}, \mathrm{K}$ at the Very Light Element condition, where voltage of $40 \mathrm{kV}$ and $250-1000 \mu \mathrm{A}$ was used to investigate $\mathrm{Ca}$, Ti, and $\mathrm{Fe}$ at the Solids $(\mathrm{S}-\mathrm{V})$ condition. The reference and measuring samples were separately excited with primary $\mathrm{X}$-ray and the emitted secondary X-ray was detected with a silicon drift detector. Loss on ignition was also included in the analysis by determining the weight loss of the sample fired at $1100^{\circ} \mathrm{C}$ for one hour.

Plate and Cone firing test was used to determine ceramics properties of raw and processed feldspar samples. The samples were plated and coned then fired at 1 hour. After that shrinkage, fired color and lustre of the plates and cones were evaluated.

The comparison of raw and processed feldspar for the chemical composition, cone shrinkage, fired color, lustre, and yield of processed were shown below.

(1) The main minerals compose in the raw materials are Na-K feldspar, quartz; with the accessory minerals comprise of muscovite, biotite and garnet [8]. The XRF chemical compositions are $75.93 \% \mathrm{SiO}_{2}, 14.34 \% \mathrm{Al}_{2} \mathrm{O}_{3}, 0.63 \% \mathrm{Fe}_{2} \mathrm{O}_{3}, 4.01 \% \mathrm{~K}_{2} \mathrm{O}, 4.34 \% \mathrm{Na}_{2} \mathrm{O}$ and $0.19 \%$ LOI. The cone shrinkage is $26.68 \%$, the fired color is $\mathrm{L}=63.10, \mathrm{a}=2.04$ and $\mathrm{b}=10.56$ with moderate lustre as shown in Fig. 10.

(2) The beneficiation of feldspar consists of crushing, grinding, classifying, attrition scrubber, wet high intensity magnetic separator, feldspar direct flotation and dry magnetic separation. The XRF chemical compositions of product after WHIMS are $76.90 \% \mathrm{SiO}_{2}, 13.97 \% \mathrm{Al}_{2} \mathrm{O}_{3}, 0.07 \%$ $\mathrm{Fe}_{2} \mathrm{O}_{3}, 4.06 \% \mathrm{~K}_{2} \mathrm{O} 4.41 \% \mathrm{Na}_{2} \mathrm{O}$ and $0.19 \%$ LOI. The cone shrinkage is $27.00 \%$, the fired color is $\mathrm{L}=86.39, \mathrm{a}=-0.68$ and $\mathrm{b}=4.15$ with moderate lustre as shown in Fig. 11.
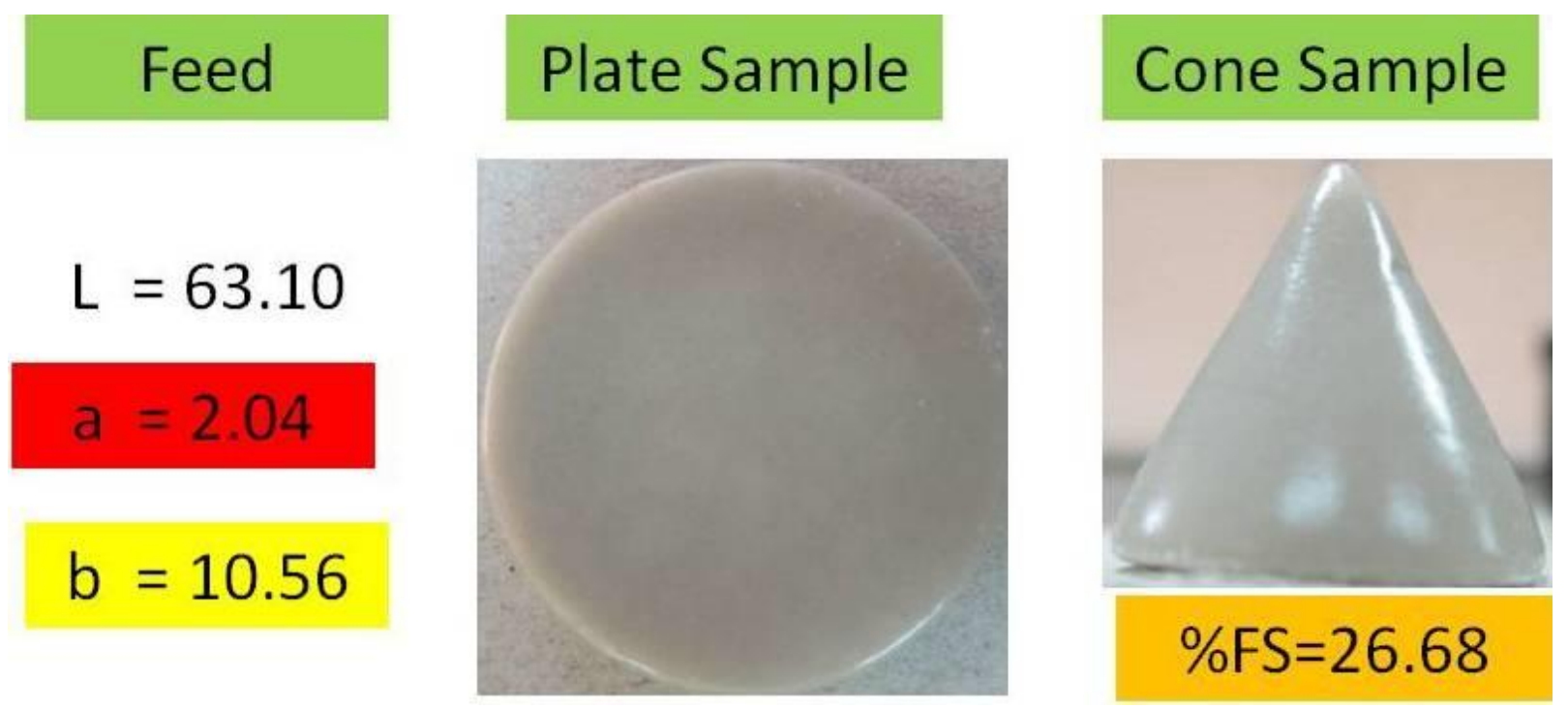

Fig. 10. Fire test result of the feed ore feldspar. 


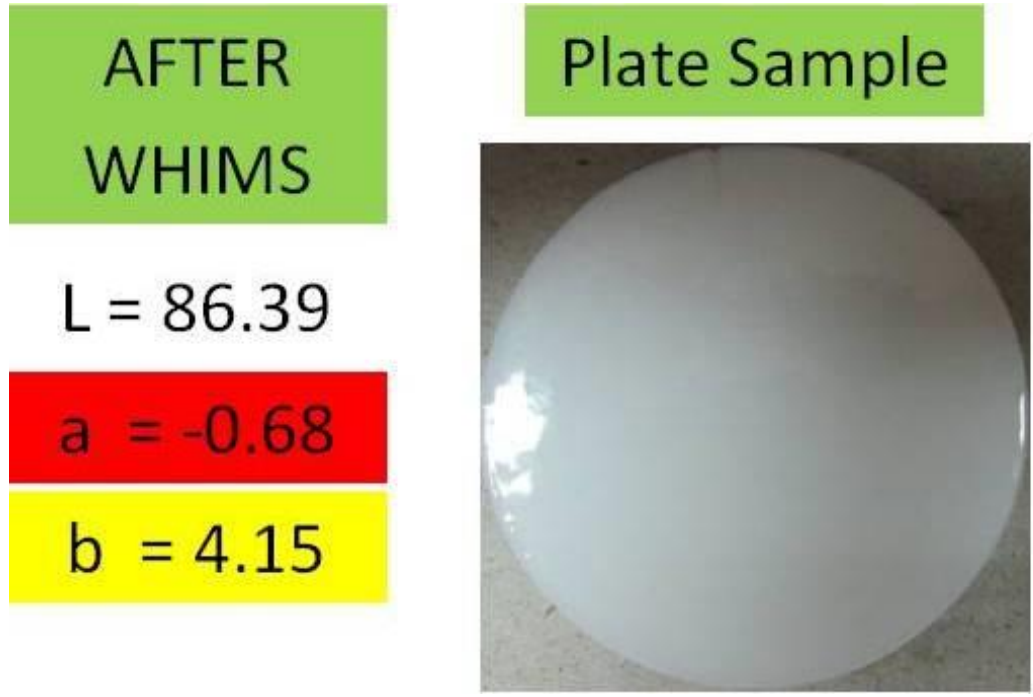

\section{Cone Sample}

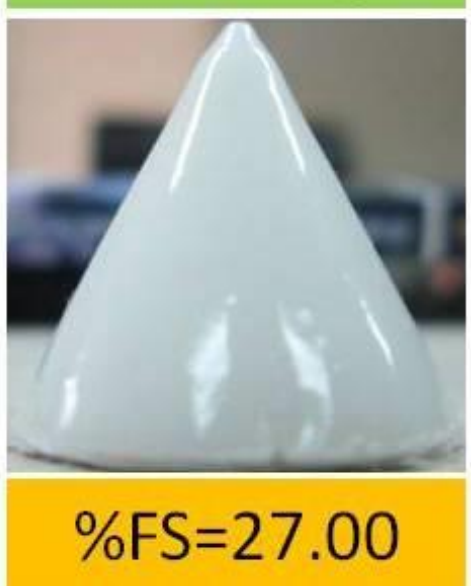

Fig. 11. Fire test result of the after WHIMS feldspar.

Yield and throughput of the processed feldspar are 40\%, 3.2 t/hr respectively. The XRF chemical compositions of final product feldspar are $68.29 \% \mathrm{SiO}_{2}, \quad 18.69 \% \mathrm{Al}_{2} \mathrm{O}_{3}, \quad 0.07 \% \mathrm{Fe}_{2} \mathrm{O}_{3}, \quad 5.83 \% \mathrm{~K}_{2} \mathrm{O}$, $6.33 \% \mathrm{Na}_{2} \mathrm{O}$ and $0.25 \% \mathrm{LOI}$. The cone shrinkage is $48.96 \%$, the fired color is $\mathrm{L}=82.10$, $\mathrm{a}=-0.56$ and $\mathrm{b}=$ 3.23 with good lustre as shown in Fig. 12.

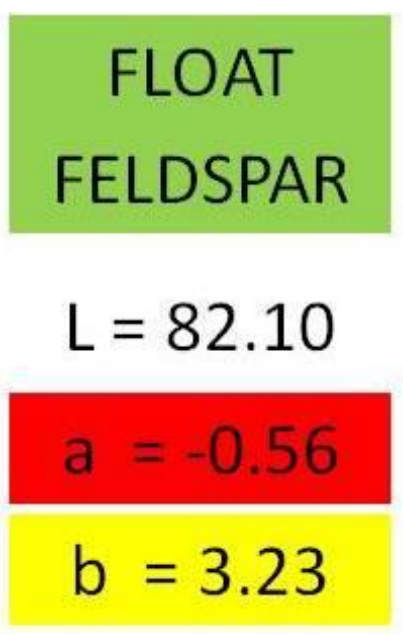

\section{Plate Sample}

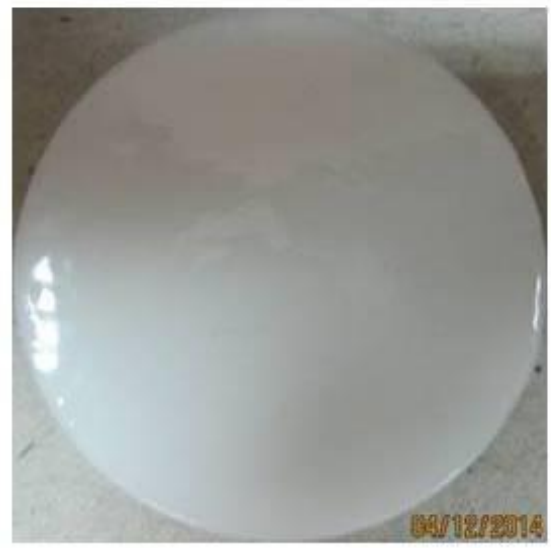

\section{Cone Sample}

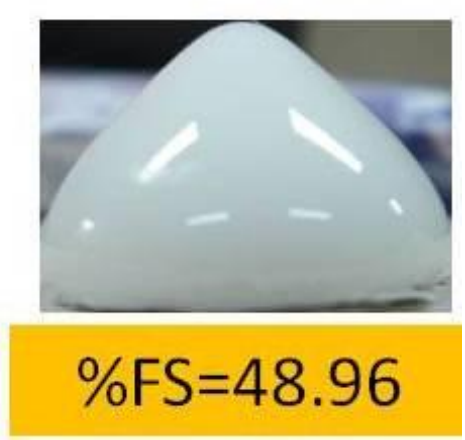

Fig. 12. Fire test result of the final product feldspar.

It is interesting to note that the cone shrinkage of final product is higher and more lustre than other samples. This phenomenon can be explained on the basis of melting property of feldspar and quartz. The melting point of feldspar and quartz are $1250^{\circ} \mathrm{C}, 1670^{\circ} \mathrm{C}$ respectively. It appears that, the final product feldspar can melt much better than other samples at fire test $1250^{\circ} \mathrm{C}$.

Rattanakawin, et al. (2010) investigated the standard floated Na-K feldspar obtained from convention process of reverse flotation with the same manufacturer. The XRF chemical compositions were $68.47 \% \mathrm{SiO}_{2}, 17.84 \% \mathrm{Al}_{2} \mathrm{O}_{3}, 0.10 \% \mathrm{Fe}_{2} \mathrm{O}_{3}, 5.94 \% \mathrm{~K}_{2} \mathrm{O}, 5.81 \% \mathrm{Na}_{2} \mathrm{O}$ and $0.44 \%$ LOI. The cone shrinkage was $47.67 \%$ with good lustre [9]. It shows that WHIMS can reduce iron bearing minerals in the feldspar rock better than reverse flotation. 


\section{Conclusion}

The proposed feldspar upgrading process that using WHIMS to substitute the conventional process of reverse flotation that consume high volume of sulphuric acid [8], make the new process environmental friendly. In addition, the process was implemented in the commercial scale with zero discharge. This paper may initiate the promotion of the efficient and environmental friendly process to the other feldspar processing plants.

\section{Acknowledgment}

The authors wish to express thanks and appreciation to Attanee International Co., Ltd. for useful information. The authors would also like to thank anonymous reviewer of the journal for providing helpful comments in an earlier version of the paper. However, the authors only are responsible for any remaining error in the paper.

\section{References}

[1] C. Patamasut, "Feldspar Flotation for ceramic industry," in Proceedings the $3^{\text {rd }}$ Conference on Mining, Pattaya, pp. 1989, 463-471.

[2] M. A. Amarante, A. Botelho de Sousa, A., and M. Machado Leite, "Beneficiation of a feldspar ore for application in the ceramic industry," The Journal of The South African Institute of Mining and Metallurgy, vol. 97, no. 4, pp. 193-196, 1997.

[3] I. Bayraktar, S. Ersayin, and Ö. Y. Gülsoy, "Upgrading titanium bearing Na-feldspar by flotation using sulphonates, succinamate and soaps of vegetable oils," Mineral Engineering, vol. 1, no. 12, pp. 1363 1374, 1997.

[4] M. M. Alimon and N. Ahmad, "Malaysian feldspar: Evaluation and processing of selected deposits," Journal of Engineering Science, vol. 7, pp. 27-35, 2011.

[5] C. Karaguzel, I. Gulgonul, C. Demir, M. Cinar, and M.S. Celik, "Concentration of K-feldspar from a pegmatitic feldspar ore by flotation," International Journal of Mineral Processing, vol. 81, pp. 122-132, 2006.

[6] E. C. Orhan and I. Bayraktar, "Amine-oleate interactions in feldspar flotation," Mineral Engineering, vol. 19, pp. 48-55, 2006.

[7] I. Gulgonul, C. Karaguzel, and M. S. Celik, "Surface vs. bulk analyses of various feldspars and their significance to flotation," International Journal of Mineral Processing, vol. 81, pp. 122-132, 2006.

[8] S. Saisinchai and T. Boonpramote, "Raw material value added for ceramic glasses gypsum industries and products," in Report of Investigation for Bureau of Primary Industries. Department of Primary Industries and Mines, Bangkok, Thailand, 2006, pp. 10-31-10-39.

[9] C. Rattanakawin, S. Phuvichit, Y. Panjasawatwong and S. Supapia, "Processing of hornblende syenite for ceramics," Songklanakarin Journal of Science and Technology, vol. 32, no. 2, pp. 189-195, Mar.-Apr., 2010. 